Discourse and Communication for Sustainable Education, vol. 12, no. 1, pp. 67-84, 2021

\title{
The Relationship Between the Lifelong Learning Tendencies and Teacher Self-Efficacy Levels of Social Studies Teacher Candidates ${ }^{1}$
}

\author{
Kubilay Yazıcı, Ebru Ay, Salih Uslu and Soner Arık \\ Niğde Ömer Halisdemir University, Niğde, Turkey
}

\begin{abstract}
Lifelong learning emerges as an important dimension in the implementation of sustainable education policies of countries. The conception of developing citizenship competencies, which is at the centre of social studies, plays an important role in shaping the lifelong learning process. The purpose of this study is to analyse the lifelong learning tendencies and teacher self-efficacy levels of social studies teacher candidates in terms of different variables and to determine the relationship between social studies teacher candidates' lifelong learning tendencies and teacher self-efficacy levels. The study group of the research consists of 307 social studies teacher candidates studying at the education faculty of a public university in the 2016-2017 academic years. The data collection tools used in the research, which was designed in relational survey model, are "Lifelong Learning Tendency Scale” developed by Diker Coşkun (2009), “Teachers' Sense of Efficacy Scale” adapted into Turkish by Çapa, Çakıroğlu and Sarıkaya (2005) and a Personal Information Form prepared by the researchers. The data of the study are analysed using SPSS 24 statistical software. As a result of the research, it is found that the lifelong learning tendency levels of the social studies teacher candidates are high and their teacher selfefficacy levels are very high. Lifelong learning tendencies and teacher self-efficacy levels of teacher candidates show statistically significant differences in terms of grade level, and taking education for personal and professional development. It is concluded that teacher self-efficacy levels of teacher candidates are a significant predictor of their lifelong learning tendencies.
\end{abstract}

Key words: lifelong learning, teacher self-efficacy, social studies, teacher candidates

\section{Introduction}

Expectations and standards in economic, social, military, educational and other fields have also changed throughout the historical process during which transitions from hunter-gatherer societies to agriculture, industry and then to the information society have taken place. The tight competition that individuals have had to keep up with in both social and professional context in the age of information, where science and technology 
have developed tremendously and still continue to evolve rapidly, has brought about large-scale changes in the competencies and qualifications needed. These competencies and qualifications, which include transferable and multifunctional knowledge, skills and behaviours, are considered necessary in terms of personal development, participation and employability in lifelong learning (European Commission, 2018, p. 7).

Lifelong learning includes the changes and transformations that occur in cognitive, affective and behavioural learning along with biological development in the process from birth till death. According to Jarvis (2006, p. 134), a more experienced person emerges when an individual's cognitive, emotional and social life integrates with relevant biography in a lifelong process. In this sense, lifelong learning helps individuals acquire more complex skills throughout their lives, which makes it one of the most vital skills and competencies (Nguyen, Chen, Do, Jun, Choi, \& Kim, 2020, p. 1; Salìte, 2016; Salìte et al., 2020). Erdamar Koç (2007, p. 214) expresses lifelong learning as understanding the world and oneself, gaining new knowledge, skills and power, the real value you will never lose, investing in oneself, creating something and realizing new beauties in the world.

Lifelong learning shows continuity from cradle to grave. Basic education starting from early childhood and subsequent vocational education and training aims to provide the new basic skills required in a knowledge-based economy for all young people (Commission of the European Communities, 2000, p. 7). For this purpose, the knowledge, skills and attitudes that the individual has gained throughout life should be updated in accordance with both the conditions of the day (Aslandağ Soylu, 2013, p. 23) and the needs of further generations as lifelong learning is also considered an indispensable component of sustainable development (Noguchi, Guevara, \& Yorozu, 2015). Sustainable development refers to the development of environmentally, socially, economically and culturally balanced communities (El-Deghaidy, 2012; Heasly et al., 2020) and has become a priority for a great variety of countries all around the world (Khumalo, 2019). According to UNESCO (2017), for a society to achieve sustainable development, individuals in that society need to be competent in understanding relationships and systems, creating visions for the future, reflection on norms and values, developing and implementing innovative actions, learning from others, doing teamwork successfully, questioning norms, practices and opinions, reflecting on their own roles in the community, and solving complex sustainability problems. These competencies are regarded as "challenging to conceptualize and measure" (Merritt, Archambault, \& Hale, 2018, p. 19), which makes it important to train especially teacher candidates so that they can improve such competencies in their future students. Consequently, these have started to take a primary place within curriculum all around the world (Guanio-Uluru, 2019). Faris (2001) states that what lies at the heart of socially, economically, culturally and environmentally sustainable societies are lifelong learning practices, whether formal or non-formal, that are encouraged and systematically implemented. In other words, considering the broad and complex nature of sustainability, lifelong education is regarded as vital and indispensable in improving societies socially, economically, culturally and environmentally (KostoulasMakrasis \& Makrasis, 2012). This is because societies need to be continuously learning societies to keep up with the continuous and rapid social, economic, cultural and environmental changes in the global world and to achieve sustainable development (Mosweunyane \& Molosi-France, 2017). Tight (1998) emphasizes the importance of implementing lifelong learning not only for societies but also for individuals and organizations to over- 
come the difficulties they face in the increasingly competitive world. Similarly, Blewitt (2006) also argues that lifelong learning is very important for sustainable development.

In the Lifelong Learning Strategy Document of Turkey, the concept is explained as any kind of learning activities individuals participate in throughout their lives with an approach related to personal, social and employment issues in order to develop their knowledge, skills, interests and competencies (Ministry of Education [MEB], 2009, p. 7). The essence of lifelong learning constitutes three basic elements: "economic progress and development", "personal development and satisfaction" and "social inclusion together with democratic understanding and behaviour" (Chapman \& Aspin, 1997, p. 27). The commission set up by the European Union for lifelong learning including these dimensions has identified key competences. These qualifications are as follows (European Commission, 2018):

- "Communication competencies in the mother tongue.

- Communication competencies in a foreign language.

- Mathematical competency and basic competencies in science and technology.

- Digital competency.

- Learning to learn.

- Social and citizenship competencies.

- Sense of initiative and entrepreneurship.

- Cultural awareness and expression competencies" (p. 7).

Lifelong learning, which represents the learning and development of an individual throughout life (Jackson, 2011, p. 2), consists of three layers, which are represented by "formal, non-formal and widespread learning", "personal, social and professional developments" and "factors such as skill, competency, age, motivation, attitude, cultural structure, teacher as the role model, learning by having fun, experience, economics, politics, information and communication technologies, and literacy that affect the lifelong learning process of the individual” respectively (Gününç, Odabaşı, \& Kuzu, 2012, p. 313318). Therefore, lifelong learning includes "all kinds of knowledge, skills, attitudes and behaviours that the individual gains through education, regardless of the age and place limit brought by formal education” (Samanc1 \& Ocakc1, 2017, p. 712).

While lifelong learning includes the education that the individual receives from primary school to university during the formal learning process, especially the individual's university education, plays a strategic role in the development of lifelong learning (Nesbit, Dunlop, \& Gibson, 2007, p. 38), because university is responsible for evaluating how it can help students become effective learners for the rest of their lives (Barnett, 2011, p. 31). In the words of Jackson $(2011$, p. 3), university education both improves the self-awareness of the individual and prepares the individual to deal with complex world problems. In addition, university education affects the self-efficacy of students as well. Thanks to their self-efficacy perceptions, students make inferences about their personal skills and abilities and realize how much of what they have learned during their education and training they can transfer into their lives (Schunk, 2004; cited from Şahin, 2010, p. 26).

The concept of self-efficacy is expressed by Bandura in Social Learning Theory as a feature that is acquired from various sources of information transferred directly and indirectly and that affects the formation of individuals' behaviours (Bandura, 1977, p. 193-194, 203). Consequently, self-efficacy, which is an active belief system that can change based on the environment, conditions and duties of any individual, also expresses 
the individuals' perceptions and judgments about their abilities to perform an activity, duty, performance or responsibility (Delinger et al., 2008, p. 752). Hobmair (2012; cited from Pröbstl and Schmidt-Hönig, 2019, p. 51), who has defined self-efficacy and presented the indicators of low and high self-efficacy in Figure 1, expresses self-efficacy as the individual's belief in being able to dominate any probable situation, influence events and control one's life. According to this, high self-efficacy manifests itself in the form of high effort, great endurance and success in situations encountered. On the other hand, low self-efficacy may bring along negative consequences such as avoidance of effort, low stamina and situational failures.

\section{Figure 1}

The Manifestation of Self-Efficacy

\begin{tabular}{|c|c|}
\hline \multicolumn{2}{|c|}{$\begin{array}{c}\text { Self-Efficacy } \\
\text { The conviction that one can master certain situations, } \\
\text { effect something and control one's life }\end{array}$} \\
\hline $\begin{array}{c}\text { High Self-Efficacy } \\
\text { Increased efforts, great stamina, } \\
\text { accomplishment of the situation probable }\end{array}$ & $\begin{array}{c}\text { Low Self-Efficacy } \\
\text { Reduced efforts and stamina, } \\
\text { probable situational failure }\end{array}$ \\
\hline
\end{tabular}

Hobmair, 2012; cited from Pröbstl and Schmidt-Hönig, 2019, p. 51

Considering the concept of self-efficacy in teaching profession, teacher competence refers to the belief of teachers in their abilities to arrange and implement the action plans that will serve to fulfil a particular teaching task successfully (Tschannen-Moran, Woolfolk Hoy, \& Hoy, 1998). In other words, teacher competence is the belief of teachers in what they can manage in terms of teaching profession (Yoo, 2016) and in their personal competencies to motivate and encourage their students to learn (Bandura, 1995 , p. 17). Teacher self-efficacy is vital for teaching and learning process and seen as both the premise and the result of teaching activities, also affects teachers' teaching practices regardless of their cultural backgrounds (Vieluf, Kunter, \& van de Vijver, 2013 , p. 97). In this context, teachers' self-efficacy beliefs serve an important function in their professional development by affecting their efforts, desire levels and the goals (Hoy \& Spero, 2005, p. 345).

Professional developments of individuals and their levels of self-efficacy about their professional developments are of great importance in the effectiveness of lifelong learning as teacher self-efficacy is directly proportional to the levels of teachers' professional optimism, professional compliance (McLennan, McIlveen, \& Perera, 2017), professional commitment and professional satisfaction (Caprara, Barbaranelli, Borgogni, \& Steca, 2003). As for the relation between teacher self-efficacy and students, it is also revealed that teacher self-efficacy is highly influential on both students' participation in educational activities (Good \& Brophy, 2003) and their academic achievement (Fackler \& Malmberg, 2016). More specifically, in order to achieve effective learning in lifelong learning, lifelong learners must have qualities such as 'being able to control their own learning processes, take responsibility and use high-level thinking skills such as "problem solving”, "having 
self-control skills", "being open to innovations and change", "being competent in the use of information and communication technologies", and "being willing to communicate" (Epçaçan, 2013, p. 357). It is claimed that teachers' teaching self-efficacy beliefs start to develop during their university years (Hoy \& Spero, 2005) and that teacher candidates' teacher self-efficacy levels are coherent about their teacher self-efficacy levels as teachers (Stites, Rakes, Noggle, \& Shah, 2018).

At this point, the social studies lesson that focuses on citizenship competencies for the learning process of the future generations to be more qualified and the social studies teachers, who are the executives of the social studies lesson, serve an important function. In this respect, this study aims to investigate the lifelong learning tendencies and teacher self-efficacy levels of social studies teacher candidates and to determine the relationship between their lifelong learning tendencies and teacher self-efficacy levels. The research questions for this purpose are as follows: 1. What are the lifelong learning tendencies and teacher self-efficacy levels of social studies teacher candidates? 2. Do the lifelong learning tendencies and teacher self-efficacy levels of social studies teacher candidates differ significantly in terms of the gender, grade level, taking education for personal and professional development and the desire to undertake postgraduate education variables? 3. Is there a statistically significant relationship between social studies teacher candidates' lifelong learning tendencies and teacher self-efficacy levels?

\section{Research Method}

\section{Research Model}

Relational survey model was used in the research to examine the lifelong learning tendencies and teacher self-efficacy levels of social studies teacher candidates and to determine the relationship between their lifelong learning tendencies and teacher selfefficacy levels. Relational survey model is a "quantitative research model that aims to determine the presence and/or degree of co-exchange between two and more variables" (Karasar, 2010, p. 81).

\section{Study Group}

The study group of the research consists of 307 social studies teacher candidates, 161 and 146 of whom being male and female respectively, who studied in the faculty of education faculty at a public university in the 2016-2017 academic years. The group is comprised of university students from different grades 75, 74, 71 and 87 of whom study at the $1^{\text {st }}, 2^{\text {nd }}, 3^{\text {rd }}$ and $4^{\text {th }}$ grades respectively.

\section{Data Collection Tools}

The data collection tools are "Lifelong Learning Tendency Scale" developed by Diker Coşkun (2009), “Teachers' Sense of Efficacy Scale” adapted to Turkish by Çapa, Çakıroğlu and Sarıkaya (2005) and a Personal Information Form prepared by the researchers. 


\section{Lifelong Learning Tendency Scale}

The "Lifelong Learning Tendency Scale" developed by Diker Coşkun (2009) consists of 27 items within four sub-dimensions, namely "motivation", "persistence", "lack of regulation in learning" and "lack of curiosity". The scale is a 6-point Likert type, and its items are rated as "fits a lot", "partially fits", "fits little ", "does not fit little”, "does not fit partially", "and "does not fit at all”. The Cronbach Alpha internal consistency coefficient calculated for the overall scale was .89 (Diker Coşkun, 2009). In this research, the reliability coefficient of the scale was calculated as .86 .

\section{Teachers' Sense of Efficacy Scale}

The original “Teachers' Sense of Efficacy Scale” adapted to Turkish by Çapa, Çakıroğlu and Sarıkaya (2005) was developed by Tschannen-Moran and Hoy (2001). The scale consists of 24 items and three sub-dimensions namely "competence for student participation", "competence for teaching strategies" and "competence for classroom management". The scale is of 9-point Likert type and its items are rated as "incompetent", "very little competent", "a little competent", "quite competent" and "very competent". Cronbach alpha reliability coefficient for the overall scale was found .93 (Çapa, Çakıroğlu, \& Sarıkaya, 2005). In this research, the reliability coefficient was calculated as .95 .

\section{Data Analysis}

The data were analysed using IBM SPSS 24 statistical software. KolmogorovSmirnov normal test was performed to see if the research data showed excessive deviation from the normal distribution. As a result of the test, it was determined that the distribution of total attitude scores did not deviate excessively from the normal distribution $(\mathrm{p}>0.05)$. In addition, the homogeneity of variances was tested by Levene F Test and it was found that the variables showed a homogenous distribution $(\mathrm{p}>0.05)$. The data were analysed through parametric tests namely unpaired t-Test, One-Way Variance Analysis and Simple Regression Analysis. As a significant difference emerged because of the analyses, the homogeneity of the variances was checked to determine between which groups the difference was. As a result of the homogeneity of the variances, Scheffe test, which is one of the multiple comparison tests, was used.

\section{Research Findings}

In this section, the findings obtained for the sub-problems mentioned in the research are included. Data including descriptive statistics about the scores of social studies teacher candidates from the Lifelong Learning Tendency Scale and Teachers' Sense of Efficacy Scale are presented in Table 1. 


\section{Table 1}

Descriptive Statistics on Lifelong Learning Tendency Scale and Teachers' Sense of Efficacy Scale

\begin{tabular}{lcccccc}
\hline & $\mathrm{N}$ & Min. & Max. & X & Ss & Level \\
\hline Lifelong Learning Tendency Scale & 307 & 42.00 & 162.00 & 118.80 & 22.34 & Partially fits \\
Teachers' Sense of Efficacy Scale & 307 & 41.00 & 247.00 & 109.68 & 32.34 & Very competent \\
\hline
\end{tabular}

According to Table 1, the average score that teacher candidates took from the Lifelong Learning Tendency Scale was 118.80 and standard deviations were 22.34. As for the Teachers' Sense of Efficacy Scale, it is seen that the average score and standard deviations were 109.68 and 32.34 respectively. In line with these data, the lifelong learning tendency levels of teacher candidates are high at the level of "partially fits" and their levels of teacher self-efficacy are very high at the "very competent" level.

Whether there is a statistically significant difference between the scores of social studies teacher candidates from the Lifelong Learning Tendency Scale and the Teachers' Sense of Efficacy Scale was analysed by Independent Samples t-Test and the findings are given in Table 2 .

\section{Table 2}

Independent Samples t-Test Results According to Gender Variable

\begin{tabular}{cccccccc}
\hline Scales & Groups & $\mathrm{N}$ & $\mathrm{X}$ & $\mathrm{Ss}$ & $\mathrm{t}$ & $\mathrm{sd}$ & $\mathrm{P}$ \\
\hline \multirow{2}{*}{ Lifelong Learning Tendency Scale } & Female & 161 & 121.06 & 22.61 & \multirow{2}{*}{1.913} & \multirow{2}{*}{305} & \multirow{2}{*}{057} \\
& Male & 146 & 116.19 & 21.84 & & & \\
\multirow{2}{*}{ Teachers' Sense of Efficacy Scale } & Female & 161 & 156.39 & 33.70 & \multirow{2}{*}{.740} & 305 & .460 \\
& Male & 146 & 159.12 & 30.81 & & & \\
\hline
\end{tabular}

According to Table 2, although the Lifelong Learning Tendency Scale scores of female teacher candidates are higher than those of male teacher candidates, it is not statistically significant $(\mathrm{p}>0.05)$. Besides, although male teacher candidates' scores from the Teachers' Sense of Efficacy Scale are higher $(\mathrm{p}>0.05)$, it is not statistically significant either. According to these findings, it can be understood that gender is not an effective factor on teacher candidates' lifelong learning tendency and teacher selfefficacy scores.

The results of the One-Way Variance Analysis applied in order to determine whether the social studies teacher candidates' scores from the Lifelong Learning Tendency Scale and the Teachers' Sense of Efficacy Scale differ according to the grade level are given in Table 3. 


\section{Table 3}

The Results of One-Way Variance Analysis According to Grade Level Variable

\begin{tabular}{|c|c|c|c|c|c|c|c|c|c|c|c|}
\hline$\frac{\mathscr{u}}{\widetilde{J}}$ & Grade & $\mathrm{n}$ & $\overline{\mathrm{X}}$ & Ss & VK & KT & sd & $\mathrm{KO}$ & $\mathrm{F}$ & $\mathrm{p}$ & 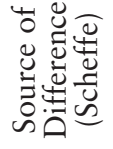 \\
\hline \multirow{4}{*}{ 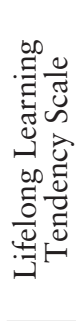 } & $\begin{array}{c}1^{\text {st }} \\
\text { grade }\end{array}$ & 75 & 112.88 & 22.82 & $\begin{array}{l}\text { Between } \\
\text { Groups }\end{array}$ & 4144.917 & 3 & 1381.639 & \multirow{4}{*}{2.817} & \multirow{4}{*}{$.039 *$} & \multirow{4}{*}{$1-4$} \\
\hline & $\begin{array}{c}2^{\text {nd }} \\
\text { grade }\end{array}$ & 74 & 118.81 & 22.46 & $\begin{array}{l}\text { Within } \\
\text { Groups }\end{array}$ & 148625.754 & 303 & \multirow{3}{*}{490.514} & & & \\
\hline & $\begin{array}{l}3^{\text {rd }} \\
\text { grade }\end{array}$ & 71 & 119.76 & 21.93 & Total & 152770.671 & 306 & & & & \\
\hline & $\begin{array}{l}4^{\text {th }} \\
\text { grade }\end{array}$ & 87 & 122.89 & 21.45 & & & & & & & \\
\hline \multirow{4}{*}{ 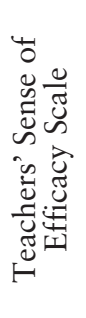 } & $\begin{array}{c}1^{\text {st }} \\
\text { grade }\end{array}$ & 75 & 154.60 & 34.48 & $\begin{array}{c}\text { Between } \\
\text { Groups }\end{array}$ & 2622.501 & 3 & 874.167 & \multirow{4}{*}{.835} & \multirow{4}{*}{.476} & \\
\hline & $\begin{array}{l}2^{\text {nd }} \\
\text { grade }\end{array}$ & 74 & 161.95 & 36.19 & $\begin{array}{l}\text { Within } \\
\text { Groups }\end{array}$ & 317353.480 & 303 & \multirow[t]{3}{*}{1047.371} & & & \\
\hline & $\begin{array}{l}3^{\text {rd }} \\
\text { grade }\end{array}$ & 71 & 159.17 & 28.04 & Total & 319975.981 & 306 & & & & \\
\hline & $\begin{array}{l}4^{\text {th }} \\
\text { grade }\end{array}$ & 87 & 155.52 & 30.26 & & & & & & & \\
\hline
\end{tabular}

According to Table 3, no statistically significant difference exists between teacher candidates' Teachers' Sense of Efficacy Scale scores in terms of grade level $(\mathrm{F}(3-303)=$ $.835, \mathrm{p}>.05)$. On the other hand, a statistically significant difference exists between teacher candidates' Lifelong Learning Tendency Scale scores by grade level $(\mathrm{F}(3-303)=$ $2.817, \mathrm{p}<.05)$. When the Scheffe test results are examined, it is observed that $4^{\text {th }}$ grade (senior) teacher candidates have a more positive lifelong learning tendency than do $1^{\text {st }}$ grade (freshman) teacher candidates. According to these findings, the grade level variable has an impact on the lifelong learning tendencies of teacher candidates and senior teacher candidates present a more positive lifelong learning tendency compared to the freshman teacher candidates.

The results of Independent Samples t-Test applied to determine whether the scores of the social studies teacher candidates from the Lifelong Learning Tendency Scale and the Teachers' Sense of Efficacy Scale differ statistically according to educational attainment for personal and professional development are given in Table 4 . 


\section{Table 4}

Independent Samples t-Test Results According to Taking Education for Personal and Professional Development

\begin{tabular}{cccccccc}
\hline Scales & $\begin{array}{c}\text { Taking } \\
\text { Education }\end{array}$ & N & X & Ss & t & sd & P \\
\hline Lifelong Learning Tendency Scale & Yes & 54 & 120.19 & 24.25 & \multirow{2}{*}{ Ne2 } & \multirow{2}{*}{305} & .602 \\
& No & 253 & 118.43 & 21.95 & & & \\
Teachers' Sense of Efficacy Scale & Yes & 54 & 165.67 & 25.97 & 2.356 & 94.372 & $.021 *$ \\
& No & 253 & 155.98 & 33.34 & & & \\
\hline
\end{tabular}

$* \mathrm{p}<.05$

According to Table 4, although teacher candidates who have taken education for personal and professional development have higher scores on the Lifelong Learning Tendency Scale, this difference is not statistically significant $(t(305)=.305 ; \mathrm{p}>.05)$. On the other hand, it is seen that the difference between the Teachers' Sense of Efficacy Scale scores of the teacher candidates is significant in favour of those who have received education for personal and professional development $(\mathrm{t}(305)=2.356 ; \mathrm{p}<.05)$. According to these findings, it can be said that the taking education for personal and professional development is not an effective factor on the teacher candidates' lifelong learning tendencies while it has a significant impact on their teacher self-efficacy levels.

The results of Independent Samples t-Test applied to determine whether the scores of the social studies teacher candidates from the Lifelong Learning Tendency Scale and the Teachers' Sense of Efficacy Scale differ statistically according to the desire to undertake postgraduate education are given in Table 5 .

\section{Table 5}

Independent Samples t-Test Results Regarding the Desire to Undertake Postgraduate Education

\begin{tabular}{cccccccc}
\hline Scales & Desire & $\mathrm{N}$ & $\mathrm{X}$ & $\mathrm{Ss}$ & $\mathrm{t}$ & $\mathrm{sd}$ & $\mathrm{P}$ \\
\hline \multirow{2}{*}{ Lifelong Learning Tendency Scale } & Yes & 149 & 120.75 & 23.15 & \multirow{2}{*}{1.533} & \multirow{2}{*}{305} & \multirow{2}{*}{.126} \\
& No & 158 & 116.85 & 21.45 & & & \\
\multirow{2}{*}{ Teachers' Sense of Efficacy Scale } & Yes & 149 & 158.05 & 34.67 & \multirow{2}{*}{ (189 } & \multirow{2}{*}{305} & .850 \\
& No & 158 & 157.35 & 30.08 & .20 \\
\hline
\end{tabular}

According to Table 5, although the teacher candidates who want to take postgraduate education have higher scores from both Lifelong Learning Tendency Scale and Teachers' Sense of Efficacy Scale, it is seen that the differences are not statistically significant $(\mathrm{p}>.05)$. According to these findings, it can be stated that the desire for postgraduate education is not an effective factor on teacher candidates' lifelong learning tendency and teacher self-efficacy scores.

The results of the Simple Regression Analysis regarding to what extent the lifelong learning tendencies of social studies teacher candidates predict their teacher self-efficacy levels are given in Table 6. 


\section{Table 6}

The Results of the Simple Regression Analysis Regarding to What Extent the Lifelong Learning Tendencies Predict Teacher Self-Efficacy Levels

\begin{tabular}{lccccc}
\hline \multicolumn{1}{c}{ Variable } & $\mathrm{B}$ & Standard Error & $\beta$ & $\mathrm{t}$ & $\mathrm{p}$ \\
\hline Constant & 84.016 & 6.036 & - & 13.919 & .000 \\
Teachers' Sense of Efficacy Scale & .220 & .038 & .319 & 5.872 & .000 \\
\hline $\mathrm{R}=.319$ & \multicolumn{5}{c}{} \\
$\mathrm{F}=34.485$ & $\mathrm{R}^{2}=.102$ \\
\hline
\end{tabular}

According to Table 6 , the variance analysis result $(\mathrm{F}=34.485, \mathrm{p}<.01)$ is found to be significant, which shows that the regression model is significant. Considering the t-test results regarding standardized regression coefficients, it is seen that teacher selfefficacy levels are a significant predictor of teacher candidates' lifelong learning tendencies $(\mathrm{p}<0.05)$. Teacher self-efficacy level has a moderate positive relationship with the lifelong learning tendencies of teacher candidates $(R=0.319)$. In addition, it explains the $10.2 \%$ variability in teacher lifelong learning scores of teacher candidates $\left(R^{2}=0.102\right.$, $\mathrm{p}<.01)$.

\section{Discussion}

The results obtained from the current research are included in this section of the study. The results of this research are compared and discussed with the results of various related studies in the literature.

As a result of the research, it is determined that the lifelong learning tendencies of social studies teacher candidates are "high". When the literature on lifelong learning is examined, it is seen that there are studies with similar content to the results of this research. When the studies on the subject are examined; lifelong learning tendencies of teacher candidates are high in the researchers conducted by Gür Erdoğan (2014) and Yenice and Alpak Tunç (2019), good level in the research conducted by Bulaç and Kurt (2019), positive and above the median in the research conducted by Kuzu, Demir and Canpolat (2015), sufficient in the research by Evin Gencel (2013) and Şahin, Akbaşli, and Yanpar Yelken (2010), and medium-level in the research by Kılıç (2014). However, contrary to the results of this research, it has been determined in the studies conducted by Diker Coşkun and Demirel (2012) and Tunca, Alkın Şahin, and Aydın (2015) that teacher candidates' lifelong learning tendencies are low.

Another result obtained in the research is that the teacher self-efficacy levels of social studies teacher candidates are "very high". Because competence is a future-oriented decision that relates to competency perceptions rather than to the level of real competence (Hoy and Spero, 2005, p. 344), this result also reveals the teacher candidates' perceptions of teaching competency. When the literature on teacher self-efficacy is examined, it is seen that there are studies with similar results. Teacher self-efficacy levels of teacher candidates are found high in the studies conducted by Ercan Özaydın, Çavaş and Arslan Cansever (2017), and Yılmaz and Gürçay (2011). Similarly, Gürol, Altunbaş and Karaaslan (2011) have determined that teacher candidates have strong teacher self-efficacy. Teacher self-efficacy levels of teacher candidates are found at sufficient level in the research 
carried out by Oğuz (2009) and Yeşilyurt (2013). In the research conducted by Taşkın and Haciömeroğlu (2010), it was found that teacher candidates' beliefs regarding the sub-dimensions of the Teachers' Efficacy Beliefs System-Self Form correspond to the "I believe" range. On the other hand, there are also studies that have found both positive and negative results in terms of teacher self-efficacy. As an example, the results of the research by Ünlü, Kaşkaya and Kızılkaya (2017) show that while teacher candidates' self-efficacy belief levels are high in the sub-dimensions of competency in classroom management and instructional strategies, they are found low in the sub-dimension of competency in student participation. In another study that compares the teacher selfefficacy levels of teachers and teacher candidates, Tanriseven (2012) has concluded that self-efficacy perceptions of teachers are higher than those of teacher candidates, which may be regarded as a contradictory result with the result of the current research.

Considering the gender variable, it is concluded that the lifelong learning tendencies of social studies teacher candidates do not show a statistically significant difference. Similarly, it is also found in the studies by Dündar (2016), Kuzu, Demir and Canpolat (2015), Oral and Yazar (2015), Şahin, Akbaşlı and Yanpar Yelken (2010), Tunca, Alkın Şahin and Aydın (2015) that gender does not play a statistically significant role on lifelong learning tendency. Contrary to these results, Bulaç and Kurt (2019), Diker Coşkun and Demirel (2012), Evin Gencel (2013) and Kılıç (2014) have concluded that there exists a statistically significant difference between the lifelong learning tendency in terms of gender and the difference is found in favour of female teacher candidates.

As for the effect of gender on the teacher self-efficacy levels of the social studies teacher candidates, it is found that the teacher self-efficacy levels of teacher candidates do not differ statistically significantly in terms of gender. When the literature on teacher self-efficacy is examined, it is seen that there are studies with similar results. According to the result of the studies by Arık (2018), Berkant, (2017), Ercan Özaydın, Çavaş and Arslan Cansever (2017), Gürol, Altunbaş and Karaaslan (2011), Malmberg, Hagger and Webster (2014), Pendergast, Garvis and Keogh (2011), Saracaloğlu and Dinçer (2009), Saracaloğlu, Yenice and Özden (2013), Taşkın and Hacıömeroğlu (2010), Tanriseven (2012), teacher self-efficacy beliefs do not show a statistically significant difference in terms of gender. However, Demirtaş, Cömert and Özer (2011) and Oğuz (2009) have found that teacher self-efficacy levels show a statistically significant difference in favour of male teacher candidates. Similarly, it is also found by Yerilyurt (2013) that teacher self-efficacy levels of male teacher candidates are higher than those of female teacher candidates in terms of the "teaching strategies" and "classroom management" sub-dimensions of Teachers' Sense of Efficacy Scale. Contrary to this result, Ünlü, Kaşkaya and Kızılkaya (2017) have concluded that female teacher candidates' teacher self-efficacy levels were higher than those of male teacher candidates.

Considering the grade level variable, social studies teacher candidates' lifelong learning tendencies show a statistically significant difference and, when compared to those of the freshman students, this difference is in favour of senior teacher candidates. It can be stated that senior teacher candidates have a higher level of lifelong learning tendencies thanks to the increase in their awareness, increases resulting from their educational experiences. Similarly, it is found in the research conducted by Diker Coŗkun and Demirel (2012) that there is a statistically significant difference in favour of senior students. While Oral and Yazar (2015) have concluded that a significant difference exists in favour of the teacher candidates studying at the third-year, the difference in the 
scores obtained from the whole scale is found in favour of the sophomore, third-year and senior teacher candidates in the research conducted by Tunca, Alkın Şahin and Aydın (2015). However, Dündar (2016) has concluded that the lifelong learning tendencies of teacher candidates do not show a significant difference in terms of grade level variable, which contradicts with the result of the current research.

No statistically significant difference is found when the teacher self-efficacy levels of social studies teacher candidates are examined in terms of grade variable. Similarly, it has been concluded in the research by Ark (2018) and Saracaloğlu, Yenice and Özden (2013) that teacher candidates' teacher self-efficacy levels do not show a statistically significant difference in terms of grade level. There are studies, however, with contradicting results as well: Oguzz (2009) has found that teacher candidates' self-efficacy beliefs show a statistically significant difference in terms of the grade level variable, and this difference is in favour of freshman students. In their study with similar a result, Taşkın and Hacıömeroğlu (2010) have also determined that there exists a significant difference in favour of senior students. Similarly, Cochran-Smith and Zeichner (2005) and Poulou (2007) have concluded that self-efficacy levels of teacher candidates increase in direct proportion with their grade levels. While Cochran-Smith and Zeichner (2005) attribute their results to the fact that teacher candidates have more learning and teaching experience as their grade levels increase, Poulou (2007) argues that this may be due to the fact that senior students have more knowledge about teacher self-efficacy.

Lifelong learning tendencies of social studies teacher candidates do not show a statistically significant difference in terms of taking education for personal and professional development. Kuzu, Demir, and Canpolat (2015) have found a similar result in their study revealing that there is no significant difference between teacher candidates' lifelong learning tendencies and whether they receive any education (courses, seminars...) outside school.

It is concluded that teacher self-efficacy levels of social studies teacher candidates show a statistically significant difference in terms of the personal and professional educational attainment variable. Contrary to this result, it is stated in the study conducted by Berkant (2017) that there is no significant difference in the teacher self-efficacy levels of teacher candidates whether they attend course and seminars for teaching profession.

When the results obtained are examined in terms of the variable of desire to undertake postgraduate education, it is concluded that the lifelong learning tendencies of social studies teacher candidates do not show a statistically significant difference. To the contrary, it is stated in the studies conducted by Bulaç and Kurt (2019) and Dündar (2016) that lifelong learning tendencies of teacher candidates differ significantly in terms of the levels of their desire to receive postgraduate education. Similarly, Diker Coşkun (2009) has also found that students who want to do postgraduate education have high levels of lifelong learning tendency.

There is no statistically significant difference between the social studies teacher candidates' desire to undertake postgraduate education and teacher self-efficacy levels. Considering the answers given by the teacher candidates participating in the study group of the research, it can be stated that the desire to receive postgraduate education does not have an effect on the teacher self-efficacy levels of social studies teacher candidates. In the literature, no study was found in terms of the relation between the desire to do postgraduate education and teacher self-efficacy. 
Finally, the findings of the research reveal that there is a moderate positive relationship between the lifelong learning tendencies of social studies teacher candidates and their teacher self-efficacy levels, and that teacher self-efficacy levels are a significant predictor of lifelong learning tendencies. Similar results have been obtained in some studies in the literature. Gür Erdoğan (2014) has found that social studies teacher candidates' lifelong learning tendencies have a moderate and positive relationship with their orientation towards teaching profession and their desire to develop a career. Similarly, Ayra and Kösterelioğlu (2015) have concluded that there is a low but positive relationship between teachers' lifelong learning tendencies and teacher self-efficacy perceptions.

\section{Conclusions}

The results of the research show that senior social studies teacher candidates' lifelong learning tendencies are found higher than those of the freshman students. It is recommended that all the training be planned and university facilities be used in a way to support the lifelong learning tendencies of all students from the first-year to the fourthyear of university education.

It is concluded that the educational attainment of social studies teacher candidates for personal and professional development has a significant effect on their lifelong learning tendencies. For this reason, it is recommended that formal and informal teaching processes aimed at the personal and professional education of teacher candidates be included more in university education.

In this study, relational survey model is used to determine the relationship between social studies teacher candidates' lifelong learning tendencies and teacher self-efficacy levels. Further research with different research designs need to be conducted to examine the teacher candidates' lifelong learning tendencies and teacher self-efficacy levels in detail.

Note:

(1) This study was presented as an oral presentation at the VI. International Symposium on Social Studies Education on May 04-06, 2017.

\section{References}

Arık, S. (2018). The investigation of the relationship between teacher candidates' teacher self-efficacy beliefs and communication skills in terms of different variables. International Journal of Eurasia Social Sciences, 9(33), 1954-1972.

Aslandağ Soylu, B. (2013). Ĕ̈itim fakültelerindeki ögretim elemanı ve öğrencilerin hayat çapında öğrenme alışkanlıkları ve üniversite yaşamına giriş dersi üzerine bir inceleme [A review on the life-wide learning habits of faculty members and students in education faculties and the introduction to university life]. (Unpublished doctoral thesis.). Mersin University, Institute of Educational Sciences, Mersin.

Ayra, M., \& Kösterelioğlu, İ. (2015). Öğretmenlerin yaşam boyu öğrenme eğilimlerinin mesleki öz yeterlik algıları ile ilişkisi [The relationship between teachers' lifelong learning tendencies and their perceptions of professional self-efficacy]. NWSAEducation Sciences, 10(1), 17-28. http://dx.doi.org/10.17218/husbed.88537 
Bandura, A. (1977). Self-efficacy: Toward a unifying theory of behavioral change. Psychological Review, 84(2), 191-215. https://doi.org/10.1037/0033-295X.84.2.191

Bandura, A. (1995). Exercise of personal and collective efficacy in changing societies. In A. Bandura (Ed.), Self-efficacy in changing societies (pp. 1-45). UK: Cambridge University Press.

Barnett, R. (2011). Life-wide education: a new and transformative concept for higher education. In N. Jackson (Ed.), Learning for a complex world (pp. 22-38). USA: Author House.

Berkant, H. G. (2017). Öğretmen adaylarının öğretmen öz-yeterlik algıları [The preservice teachers' perceptions of teacher self-efficacy]. Journal of Educational Reflections, 1(2), 1-17.

Blewitt, J. (2006). The ecology of learning: sustainability, lifelong learning and everyday life. London: Earthscan.

Bulaç, E., \& Kurt, M. (2019). Öğretmen adaylarının yaşam boyu öğrenme eğilimlerinin incelenmesi [Investigation of tendencies of prospective teachers towards lifelong learning]. Amasya Education Journal, 8(1), 125-161. http://www.dergipark.org.tr/ tr/pub/amauefd/issue/45794/532829

Caprara, G. V., Barbaranelli, C., Borgogni, L., \& Steca, P. (2003). Efficacy beliefs as determinants of teachers' job satisfaction. Journal of Educational Psychology, 95, $821-832$.

Chapman, J. D., \& Aspin, D. N. (1997). The school, the community and lifelong learning. London and Washington: Cassell.

Cochran-Smith, M., \& Zeichner, K. M. (Eds.). (2005). Studying teacher education: The report of the AERA panel on research and teacher education. Mahwah, NJ: Erlbaum.

Commission of the European Communities. (2000). Commission staff working paper: A memorandum on lifelong learning. Brussels. https://uil.unesco.org/i/doc/lifelonglearning/policies/european-communities-a-memorandum-on-lifelong-learning.pdf

Çapa, Y., Çakıroğlu, J., \& Sarıkaya, H. (2005). The development and validation of a Turkish version of the teachers' sense of efficacy scale [Öğretmen öz-yeterlik ölçeği Türkçe uyarlamasının geçerlik ve güvenirlik çalışması]. Education and Science, 30(137), 74-81.

Dellinger, A. B., Bobbett, J. J., Olivier, D. F., \& Ellet, C. D. (2008). Measuring teacher self-efficacy beliefs: Development and use of the TEBS-Self. Teaching and Teacher Education, 24, 751-766. http://dx.doi.org/10.1016/j.tate.2007.02.01

Demirtaş, H., Cömert, M., \& Özer, N. (2011). Öğretmen adaylarının özyeterlik inançları ve ögretmenlik mesleğine ilişkin tutumları [Pre-service teachers' self-efficacy beliefs and attitudes towards teaching profession]. Education and Science, 36(159), 96-111.

Diker Coşkun, Y., \& Demirel, M. (2012). Üniversite öğrencilerinin yaşam boyu öğrenme eğilimleri [Lifelong learning tendencies of university students]. Hacettepe University Journal of Education, 42, 108-120.

Diker Coşkun, Y. (2009). Üniversite ögrrencilerinin yaşam boyu öğrenme e ğilimlerinin bazı değişkenler açısından incelenmesi [The examination of the lifelong learning tendencies of university students in terms of some variables]. (Unpublished doctoral thesis.). Hacettepe University, Institute of Social Sciences, Ankara. 
Dündar, H. (2016). Sınıf öğretmeni adaylarının yaşam boyu öğrenme ĕ̆ilimlerinin incelenmesi [The investigation of the lifelong learning tendencies of classroom teacher candidates]. (Unpublished master's thesis.). Atatürk University, Institute of Educational Sciences, Erzurum.

El-Deghaidy, H. (2012). Education for sustainable development: Experiences from action research with science teachers. Discourse and Communication for Sustainable Education, 3(1), 23-40.

Epçaçan, C. (2013). Yaşam boyu öğrenme becerilerinin ders kitaplarında yer alma düzeyine örnek bir inceleme [A sample review of the existence level of life-long learning skills in textbooks]. Adiyaman University Journal of Social Sciences, Türkçenin Eğitimi Öğretimi Özel Sayısı [Special issue on teaching Turkish education], 6(11), 353-379.

Ercan Özaydın, T., Çavaş, P., \& Arslan Cansever, B. (2017). Sınıf öğretmeni adaylarının öz-yeterlik inançlarının değerlendirilmesi [The evaluation of classroom teacher candidates' self-efficacy beliefs]. Ege Journal of Education, 18(1), 1-30.

Erdamar Koç, G. (2007). Yaşam boyu ögrrenme [Lifelong learning]. In Ö. Demirel (Ed.), Ĕ̈itimde Yeni Yönelimler [New trends in education] (pp. 213-231). Ankara: Pegem A Publishing.

European Commission. (2018). Commission staff working document accompanying the document proposal for a council recommendation on key competences for lifelong learning. https://eurlex.europa.eu/legalcontent/EN/TXT/PDF/?uri=CELEX: 52018SC0014\&from=EN

Evin Gencel, İ. (2013). Öğretmen adaylarının yaşam boyu öğrenme yeterliklerine yönelik algiları [Pre-service teachers' perceptions about lifelong learning competencies]. Education and Science, 38(170), 237-252.

Fackler, S., \& Malmberg, L. E. (2016). Teachers' self-efficacy in 14 OECD countries: Teacher, student group, school and leadership effect. Teaching and Teacher Education, 56, 185-195.

Faris, R. (2001). The way forward: Building a learning nation community by community. Working Paper. Vancouver, Canada.

Good, T. L., \& Brophy, J. E. (2003). Looking in the classroom (9 $9^{\text {th }}$ edition). Boston: Allyn \& Bacon.

Guanio-Uluru, L. (2019). Education for sustainability: Developing ecocritical literature circles in the student teacher classroom. Discourse and Communication for Sustainable Education, 10(1), 5-19.

Günüç, S., Odabaşı, F. H., \& Kuzu, A. (2012). Yaşam boyu öğrenmeyi etkileyen faktörler [Factors that affect lifelong learning]. Gaziantep University Journal of Social Sciences, 11(2), 309-325.

Gür Erdoğan, D. (2014). Öğretmen adaylarının yaşam boyu öğrenme ĕgilimlerine etki eden faktörler [Factors that affect teacher candidates' lifelong learning tendencies]. (Unpublished master's thesis.). Abant İzzet Baysal University, Institute of Educational Sciences, Bolu.

Gürol, A., Altunbaş, S., \& Karaaslan, N. (2011). Öğretmen adaylarının öz yeterlik inançları ve epistemolojik inançları üzerine bir çalışma [A study on pre-service teachers' self-efficacy beliefs and epistemological beliefs]. e-Journal of New World Sciences Academy Education Sciences, 5(3), 1395-1404. 
Heasly, B., Iliško, Dz., Salīte, I., \& Lindner, J. (2020). The value of process and pedagogy through the sustainability prism. Discourse and Communication for Sustainable Education, 11(2), pp. 1-4. https://doi.org/10.2478/dcse-2020-0014

Hoy, A. W., \& Spero R. B. (2005). Changes in teacher efficacy during the early years of teaching: A comparison of four measures. Teaching and Teacher Education, 21, 343-356.

Jackson, N. (2011). The lifelong and lifewide dimensions of living, learning and developing. In N. Jackson (Ed.), Learning for a complex world (pp. 1-21). USA: AuthorHouse. Jarvis, P. (2006) Towards a comprehensive theory of human learning. London: Routledge. Karasar, N. (2010). Bilimsel araştırma yöntemi [Scientific research method] (21 ${ }^{\text {st }}$ edition). Ankara: Nobel Publishing.

Khumalo, S. S. (2019). The role of transformational school leadership in promoting teacher commitment: An antecedent for sustainable development in South Africa. Discourse and Communication for Sustainable Education, 10(2), 22-32.

Kılıç, Ç. (2014). Öğretmen adaylarının yaşam boyu öğrenmeye yönelik algıları [Preservice teachers' perceptions towards lifelong learning]. Journal of Research in Education and Teaching, 3(4), 79-87.

Kostoulas-Makrakis, N., \& Makrakis, V. (2012). Education for sustainable development: experiences from action research with science teachers. Discourse and Communication for Sustainable Education, 3(1), 5-22.

Kuzu, S., Demir, S., \& Canpolat, M. (2015). The evaluation of life-long learning tendencies of pre-service teachers in terms of some variables [Öğretmen adaylarının yaşam boyu öğrenme eğilimlerinin bazı değişkenler açısından değerlendirilmesi]. Journal of Theory and Practice in Education, 11(4), 1089-1105.

Malmberg, L. E., Hagger, H., \& Webster, S. (2014). Teachers' situation-specific mastery experiences: Teacher, student group and lesson effects. European Journal of Educational Psychology, 29(3), 429-451.

McLennan, B., Mcllveen, P., \& Perera, H. N. (2017). Pre-service teachers' self-efficacy mediates the relationship between career adaptability and career optimism. Teaching and Teacher Education, 63, 176-185.

MEB (Ministry of Education). (2009). Hayat boyu öğrenme strateji belgesi [Lifelong learning strategy document]. Turkey. http://ecvet.ua.gov.tr/Uploads/f76993464182-4730-8282-a61938751493.pdf

Merritt, E. G., Archambault, L., \& Hale, A. E. (2018). Sustainability education in elementary classrooms: Reported practices of alumni from a pre-service teacher course. Discourse and Communication for Sustainable Education, 9(1), 18-35.

Mosweunyane, D., \& Molosi-France, K. (2017). Lifelong learning for sustainable development in the world. International Journal of Academic Research in Progressive Education and Development, 6(4), 1-12.

Nesbit, T., Dunlop, C., \& Gibson, L. (2007). Lifelong learning in institutions of higher education. Canadian Journal of University Continuing Education, 33(1), 35-60.

Nguyen, G., Chen, S., Do, T., Jun, T. J., Choi, H. J., \& Kim, D. (2020). Dissecting catastrophic forgetting in continual learning by deep visualization. arXiv preprint arXiv:2001.01578.

Noguchi, F., Guevara, J. R., \& Yorozu, R. (2015). Communities in action: Lifelong learning for sustainable development. UNESCO Institute for Lifelong Learning. Feldbrunnenstrasse, 58, 20148, Hamburg, Germany. 
Oğuz, A. (2009). Öğretmen adaylarının öğretmen öz yeterlik inançlarının incelenmesi [The examination of teacher candidates' teacher self-efficacy beliefs]. Dumlupinar University Journal of Social Sciences, 24, 281-290.

Oral, B., \& Yazar, T. (2015). Öğretmen adaylarının yaşam boyu öğrenmeye ilişkin algılarının çeşitli değişkenlere göre incelenmesi [Examining prospective teachers' perceptions of lifelong learning in terms of different variables]. Electronic Journal of Social Sciences, 14(52), 1-11.

Pendergast, D., Garvis, S., \& Keogh, J. (2011). Pre-service student-teacher self-efficacy beliefs: An insight into the making of teachers. Australian Journal of Teacher Education, 36(12), 45-58.

Poulou, M. (2007). Personal teaching efficacy and its sources: Student teachers' perceptions. Educational Psychology, 27, 191-218. doi: 10.1080/01443410601066693

Pröbstl, G., \& Schmidt-Hönig, K. (2019). Self-efficacy in social science. Discourse and Communication for Sustainable Education, 10(2), 49-59.

Salite, I. (2016). Searching for sustainability in teacher education and educational research: Experiences from the Baltic and Black Sea Circle Consortium for educational research. Discourse and Communication for Sustainable Education, 6(1), 21-29.

Salīte, I., Fjodorova, I., Iliško, Dz., Ivanova, O., \& Meihami, H. (2020). JTES for Sustainable Development: An action research environmentfor the development and sustainable future of the journal identity. Journal of Teacher Education for Sustainability, 22(1), 1-5. doi: 10.2478/jtes-2020-0001

Samanc1, O., \& Ocakcı, E. (2017). Hayat boyu öğrenme [Lifelong learning]. Bayburt Ĕ̈itim Fakültesi Dergisi [Journal of Bayburt Education Faculty], 12(24), 711722.

Saracaloğlu, A.S., \& Dinçer, B. (2009). A study on correlation between self-efficacy and academic motivation of prospective teachers. Procedia Social and Behavioral Sciences, 1, 320-325.

Saracaloğlu, A. S., Yenice, N., \& Özden, B. (2013). Fen bilgisi, sosyal bilgiler ve sınıf öğretmeni adaylarının öğretmen öz-yeterlik algılarının ve akademik kontrol odaklarinın incelenmesi [An analysis of prospective science, social sciences and primary school teachers' self-efficacy perceptions and focus of academic control]. Pamukkale University Journal of Education, 34, 227-250.

Stites, M. L., Rakes, C. R., Noggle, A. K., \& Shah, S. (2018). Preservice teacher perceptions of preparedness to teach in inclusive settings as an indicator of teacher preparation program effectiveness. Discourse and Communication for Sustainable Education, $9(2), 21-39$.

Şahin, E. (2010). İlköğretim sinı ögrretmenlerinin ögretim stili terciblerinin, cinsiyetlerinin, mesleki kıdemlerinin, öz-yeterlik algılarının ve öz-yönetimli ögrrenmeye hazırbulunuşluk düzeylerinin mesleki yeterlikleri üzerindeki etkisi [The effect of primary school teachers' teaching style preferences, gender, professional seniority, self-efficacy perceptions and self-directed learning readiness on their professional competencies]. (Unpublished doctoral thesis.). Yıldız Teknik University, Institute of Social Sciences, İstanbul.

Şahin, M., Akbaşlı, S., \& Yanpar Yelken, T. (2010). Key competences for lifelong learning: The case of prospective teachers. Educational Research and Review, 5(10), 545-556.

Tanriseven, I. (2012). Examining primary school teachers' and teacher candidates' sense of efficacy. Procedia - Social and Behavioral Sciences, 47, 1479-1484. 
Taşkın, Ş. Ç., \& Hacıömeroğlu, G. (2010). Öğretmen özyeterlik inanç ölçeğinin Türkçe’ye uyarlanması ve sınıf ögretmeni adaylarının özyeterlik inançları [The adaptation of the teacher self-efficacy belief scale into Turkish and the self-efficacy beliefs of classroom teacher candidates]. Dokuz Eylül University Buca Faculty of Education Journal, 27, 63-75.

Tight, M. (1998). Lifelong learning: Opportunity or compulsion? British Journal of Education Studies, 46(3), 251-263.

Tschannen-Moran, M., Woolfolk Hoy, A., \& Hoy, W. K. (1998). Teacher efficacy: Its meaning and measure. Review of Educational Research, 68(2), 202-248.

Tunca, N., Alkın Şahin, S., \& Aydın, Ö. (2015). Öğretmen adaylarının yaşam boyu öğrenme eğilimleri [Pre-service teachers' lifelong learning tendencies]. Mersin University Faculty of Education Journal, 11(2), 432-446.

UNESCO. (2017). Education for sustainable development goals: Learning objectives. Paris: UNESCO. https://unesdoc.unesco.org/ark:/48223/pf0000247444

Ünlü, İ., Kaşkaya, A., \& Kızılkaya, M. F. (2017). Sosyal bilgiler öğretmen adaylarının öz-yeterlik inançlarının çeşitli değişkenler açısından incelenmesi [Examining the self-efficacy beliefs of social studies teacher candidates in terms of some variables]. Ahi Evran University Kırşehir Faculty of Education Journal, 18(2), 651-668.

Vieluf, S., Kunter, M., \& van de Vijver, F. J. R. (2013). Teacher self-efficacy in crossnational perspective. Teaching and Teacher Education, 35, 92-103.

Yenice, N., \& Alpak Tunç, G. (2019). Öğretmen adaylarının yaşam boyu öğrenme eğilimleri ile bireysel yenilikçilik düzeylerinin incelenmesi [An investigation of preservice teachers' lifelong learning tendencies and their individual innovativeness levels]. Kastamonu Education Journal, 27(2), 753-765.

Yeşilyurt, E. (2013). Öğretmen adaylarının öğretmen özyeterlik algıları [Teacher selfefficacy perceptions of pre-service teachers]. Electronic Journal of Social Sciences, 12(45), 88-104.

Yılmaz, M., \& Gürçay, D. (2011). Biyoloji ve fizik öğretmen adaylarının öğretmen özyeterliklerini yordayan değişkenlerin belirlenmesi [The determination of variables that predict biology and physics teacher candidates' teacher self-efficacy]. Çukurova University Faculty of Education Journal, 1(40), 53-60.

Yoo, J. H. (2016). The effect of professional development on teacher efficacy and teachers' self-analysis of their efficacy change. Journal of Teacher Education for Sustainability, $18(1), 84-94$.

Correspondence concerning this paper should be addressed to Ebru Ay, Niğde Ömer Halisdemir University, Niğde, Turkey. Email: ebru.ay@ohu.edu.tr 